\title{
Cytoprotective activity of carrot and tomato callus extracts and the expression of cytokines in UV-B irradiated fibroblast cells
}

\author{
Rumiyati $^{1,{ }^{*}}$, Sismindari ${ }^{1}$, Endang Semiarti ${ }^{2}$, Sitarina Widyarani ${ }^{3}$, Dewi Tika Sari ${ }^{1}$, Brilliant Kharisma Apritadila ${ }^{1}$, and Anami \\ Riastri ${ }^{1}$ \\ ${ }^{1}$ Faculty of Pharmacy, Universitas Gadjah Mada, Jalan Sekip Utara, Yogyakarta 55281, Indonesia \\ ${ }^{2}$ Faculty of Biology, Universitas Gadjah Mada, Jalan Teknika Selatan, Sekip Utara, Yogyakarta 55281, Indonesia \\ ${ }^{3}$ Faculty of Veterinary Medicine, Universitas Gadjah Mada, Jalan Fauna No. 2, Yogyakarta 55281, Indonesia \\ *Corresponding author: rumiyaris@ugm.ac.id
}

SUBMITTED 1 July 2019 REVISED 14 Oktober 2019 ACCEPTED 9 December 2019

\begin{abstract}
Studies have suggested that both carrot (Daucus carota L.) and tomato (Solanum lycopersicum L.) callus extracts contain antioxidant compounds that might have the potential to protect cells from free radicals such as $\mathrm{H}_{2} \mathrm{O}_{2}$ that contribute to cell damage. The other sources of free radical exposure in human cells, such as UV-B, should also be examined. UV-B exposure can trigger increased expression of inflammatory cytokines such as cyclooxygenase-2 (COX-2) and tumor necrosis factor- $a$ (TNF-a) and the anti-inflammatory cytokine interleukin-10 (IL-10), which causes photoaging. This study was conducted to investigate the cytoprotective activity of carrot and tomato callus aqueous extracts by observing cell viability using the MTT assay. Immunocytochemistry methods were used to examine the effects of carrot and tomato callus aqueous extracts on the expression of COX-2, TNF-a, and IL-10 in human dermal fibroblast adult (HDFa) cells exposed to UV-B light. Carrot and tomato callus aqueous extracts were obtained by the maceration method using aqua bidistilled solvent. Results showed that both carrot and tomato callus aqueous extracts at $0.5 \mathrm{mg} / \mathrm{mL}$ exhibited the highest cytoprotective effect in HDFa cells compared to that at other concentrations. Both carrot and tomato callus aqueous extracts could also decrease the expression of COX-2 and TNF- $a$, whereas carrot callus aqueous extract increased the expression of the anti-inflammatory cytokine IL-10 in HDFa cells.
\end{abstract}

KEYWORDS carrot (Daucus carota L.) and tomato (Solanum lycopersicum L.) callus aqueous extract; viability cell; cyclooxygenase-2 (COX-2); tumor necrosis factor- $a$ (TNF-a); interleukin-10 (IL-10)

\section{Introduction}

Aging is a physiological process that naturally occurs in the human body. It can also be accelerated by environmental factors such as UV-B exposure. Chronic exposure of UV-B light to human skin can induce the production of reactive oxygen species (ROS), which contributes to the phenomenon of skin aging. ROS in the skin also has an ability to induce inflammatory reactions through the expression of inflammatory cytokines such as cyclooxygenase-2 (COX-2), tumor necrosis factor- $\alpha$ (TNF- $\alpha$ ), interleukin-6 (IL-6), and interleukin-10 (IL-10) (Grandjean-Laquerriere et al. 2003; Kanagalakshmi et al. 2014). The expression of these proinflammatory cytokines in cells can stimulate dermal matrix degradation and accelerate skin aging, whereas the anti-inflammatory cytokine IL-10 can prevent cells from further inflammatory reactions (Liechty et al. 2000; Kammeyer and Luiten 2015).

Schmid et al. (2008) investigated a plant stem cell extract derived from an apple tree type, Uttwiler Spätlauber, that had the ability to induce regeneration of human skin and hair. Plant stem cells can also be defined as callus, which is a mass of undifferentiated plant cells formed as a response to wounding. Previous studies have reported that both carrot and tomato callus extracts had higher antioxidant activities than tuber extracts (Hana 2016; Khristina 2017) and were also suggested to contain antioxidants such as flavonoids, phenolic compounds, and terpenoids. Furthermore, carrot callus extract contains proteins such as albumin and glycoprotein, and tomato callus extract contains unknown proteins with molecular weights ranging from approximately 19 to $108 \mathrm{kDa}$ (Hana 2016; Sekar 2016; Prastowo 2017). Previous research has also demonstrated the cytoprotective activity of carrot (Daucus carota L.) and tomato (Solanum lycopersicum L.) callus extracts in human dermal fibroblast adult (HDFa) cells against $\mathrm{H}_{2} \mathrm{O}_{2}$ exposure through the restoration of the $\mathrm{G}_{0} / \mathrm{G}_{1}$ cell cycle phase (Prastiandari 2018; Utama 2018). Furthermore, tomato callus aqueous extract was found to exhibit a higher rate of cell death inhibition induced by $\mathrm{H}_{2} \mathrm{O}_{2}$ rad- 
ical exposure than the ethanolic extract (Dewi 2018).

In this in vitro study, we reinvestigated the cytoprotective activity of both carrot and tomato callus aqueous extracts in HDFa cells irradiated by UV-B exposure in preventing cell damage by observing viable cells and the expression of COX-2, TNF- $\alpha$, and IL-10.

\section{Materials and Methods}

The following reagents were used in this study: antihuman COX-2, TNF- $\alpha$, and IL-10 antibodies, UltraTek HRP anti-polyvalent (DAB) Staining Complete System Kit containing peroxide block, super block, antipolyvalent, HRP, 3,3'-Diaminobenzidine (DAB) chromogen and DAB substrate, Entellan Mounting Media, and Mayer hematoxylin, were all obtained from ScyTek Laboratories (Utah, USA). Dulbecco's Modified Eagle Medium (DMEM) low glucose, fetal bovine serum (FBS) qualified, $2 \%$ penicillin-streptomycin, $0.5 \%$ fungizone, phosphatebuffered saline (PBS) $1 \times, 0.25 \%$ Trypsin-EDTA were all obtained from Gibco (New York, USA), and 3-(4,5dimethyl thiazole-2-il)-2,5-diphenyltetrazolium bromide (MTT) (Bio Basic Inc., Markham, Canada). Hydrogen chloride (HCl) $0.01 \mathrm{~N}, 10 \%$ sodium dodecyl sulfate, and methanol were all obtained from Merck (Darmstadt, Germany).

\subsection{Preparation of Carrot and Tomato Callus Aqueous Extracts}

Tomato ("Permata" variant) and carrot ("New Nantes" variant) calli were collected from the Biotechnology Laboratory, Faculty of Biology, Universitas Gadjah Mada. The calli of both plants were harvested at the age 30 days until 50 days after culturing the carrot and tomato explants in Murashige-Skoog (MS) medium supplemented with $\alpha$ naphthalene acetic acid (NAA) and 6-benzylaminopurine (BAP) at ratios of 1:5 and 10:1, respectively.

The calli of both plants were prepared by weighing and macerating in aqua bidistilled water ( $1 \mathrm{~g}$ wet tissue per $5 \mathrm{~mL}$ aqua bidistilled water) at $4^{\circ} \mathrm{C}$ for $3 \mathrm{~h}$. The macerates were then centrifuged at $12000 \mathrm{rpm}$ for $12 \mathrm{~min}$. The remaining solution (supernatant) was later freeze-dried to remove the solvent.

\subsection{Cell Culture}

HDFa cell lines (Catalog number C-013-5C, Lot number 1712286) (Gibco) were kindly provided by Dr. Arief Nurrochmad, M.Sc., Apt (Universitas Gadjah Mada) and were cultured in DMEM low glucose media supplemented with $10 \%$ FBS, $0.5 \%$ fungizone, and $2 \%$ penicillinstreptomycin. The cells were maintained in an incubator at $5 \% \mathrm{CO}_{2}$ and $37^{\circ} \mathrm{C}$ and were cultured until they reached $80 \%$ confluence using $0.25 \%$ Trypsin-EDTA.

\subsection{Analysis of Cytoprotective Effect by MTT Assay (Cellular Viability Assay)}

The HDFa cultures were seeded at a density of $2 \times 10^{4}$ cells/well in a 96-well plate and then incubated overnight in an incubator at $5 \% \mathrm{CO}_{2}$ and $37^{\circ} \mathrm{C}$. Next, the cells were treated with either the carrot or tomato callus extract at three different concentrations and incubated for an additional $4 \mathrm{~h}$. After irradiation, the medium was replaced with PBS solution and irradiated with a UV-B lamp (FS40T12UVB-BP Light Sources) at $60 \mathrm{~mJ} / \mathrm{cm}^{2}$ for $198 \mathrm{~s}$. Immediately after irradiation, the PBS solution was replaced with the medium for cell culture, and the cells were incubated for $24 \mathrm{~h}$. After this procedure, the cell viability was analyzed using the MTT assay protocol (ATCC 2011), and the absorbance was measured at $550 \mathrm{~nm}$. Cells incubated only with control medium were considered to be $100 \%$ viable.

\subsection{Analysis of COX-2, TNF- $\alpha$, and IL-10 Expression in HDFa Cells Using Immunocytochemistry Method}

The HDFa cultures were seeded at a density of $5 \times 10^{4}$ cells/well in a 24-well plate. For immunocytochemistry analysis, cover slips were placed on each well, and the cells were transferred onto the cover slips and then incubated for 3-30 min in an incubator at $5 \% \mathrm{CO}_{2}$ and $37^{\circ} \mathrm{C}$ to enable adhesion of cells. Cells were treated with either the carrot or tomato callus extract at the concentration that provided the highest viability of cells in a previous experiment conducted using the MTT assay and then incubated for an additional $4 \mathrm{~h}$. Next, the cells were irradiated with UV-B light at $60 \mathrm{~mJ} / \mathrm{cm}^{2}$ and incubated for $24 \mathrm{~h}$. Fixation was done by adding methanol for $5 \mathrm{~min}$.

Next, 3\% $\mathrm{H}_{2} \mathrm{O}_{2}$ (blocking solution) and blocking serum were added to each well subsequently and incubated for 5-10 min. For immunolabeling, the cells were incubated with the primary monoclonal antibody specific for COX-2, TNF- $\alpha$, and IL-10 for 30-45 min, and after two times washing with PBS, a biotinylated secondary antibody (UltraTek anti-polyalent) and a streptavidinperoxidase complex reagent (UltraTek HRP) were applied according to the manufacturer's protocol. After several times of washings at each step with PBS (pH 7.4), DAB solution was added and incubated for 1-5 min, followed by counterstaining with Mayer hematoxylin. Then, cover slips were placed on each well and dissolved at increasing concentrations of alcohol for $4 \mathrm{~min}$, and finally, the cells were mounted onto slides using the mounting media. The cell preparations were observed under a microscope, and the images were analyzed for cytokine expression using the ImageJ software.

\section{Results and Discussion}

\subsection{Preparation of Carrot and Tomato Callus Aqueous Extracts}

The process of carrot and tomato callus extraction resulted in percentage yields of $1.16 \%$ and $1.18 \%$, respectively. The physical characteristics of the callus showed variations in color from white-yellowish, white-greenish, and slightly brownish, with a friable texture and were compact. The extracts of both carrot and tomato calli obtained from the maceration procedure were processed for further test- 


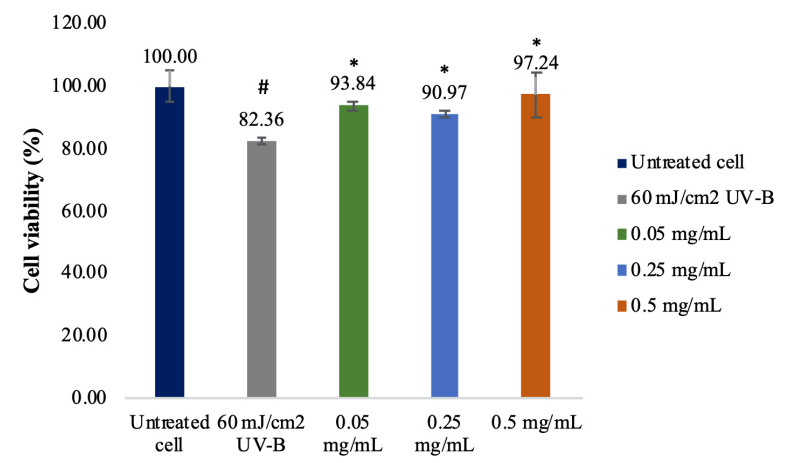

FIGURE 1 HDFa cellular viability analysis with carrot callus extract in aqueous solution. The results showed that UV-B exposure significantly decreased the cell viability compared with untreated cell (\# $p<0.05)$ and carrot callus extract with varying concentrations significantly increased the cell viability if compared with $60 \mathrm{~mJ} / \mathrm{cm}^{2}$ UV-B irradiated cells without pre-treatment extract $\left({ }^{*} \mathrm{p}<0.05\right)$. Data are shown as a percentage of cell viability \pm standard error based on one time experiment using three wells.

ing in this study.

\subsection{Analysis of Cytoprotective Effect of Carrot and Tomato Callus Aqueous Extracts by MTT Assay}

The cytoprotective test was used to evaluate the ability of the callus extract to protect HDFa cells from UV-B exposure. The cytoprotective effect was determined by the MTT assay based on the formation of formazan crystals measured at an absorbance of $550 \mathrm{~nm}$. The cytoprotective effect of the callus extract was evaluated at three different concentrations on the basis of a previous study, i.e., 0.05, 0.25 , and $0.5 \mathrm{mg} / \mathrm{mL}$ for the carrot callus extract and 0.15 , 0.5 , and $1.0 \mathrm{mg} / \mathrm{mL}$ for the tomato callus extract (Rumiyati et al. 2019).

The results showed that UV-irradiated cells exhibited an inhibitory effect by resulting in $82.36 \% \pm 1.30 \%$ of cell viability. Pretreatment with the carrot callus extract at $0.05,0.25$, and $0.5 \mathrm{mg} / \mathrm{mL}$ resulted in cell viabilities of $93.84 \% \pm 0.87 \%, 90.97 \% \pm 0.66 \%$, and $97.24 \% \pm 4.05 \%$, respectively (Figure 1). Pretreatment with the tomato callus extract at $0.15,0.5$, and $1.0 \mathrm{mg} / \mathrm{mL}$ resulted in cell viabilities of $92.56 \% \pm 0.79 \%, 103.77 \% \pm 1.77 \%$, and $97.45 \% \pm 1.44 \%$, respectively (Figure 2 ). These results indicated that both carrot and tomato callus extracts had

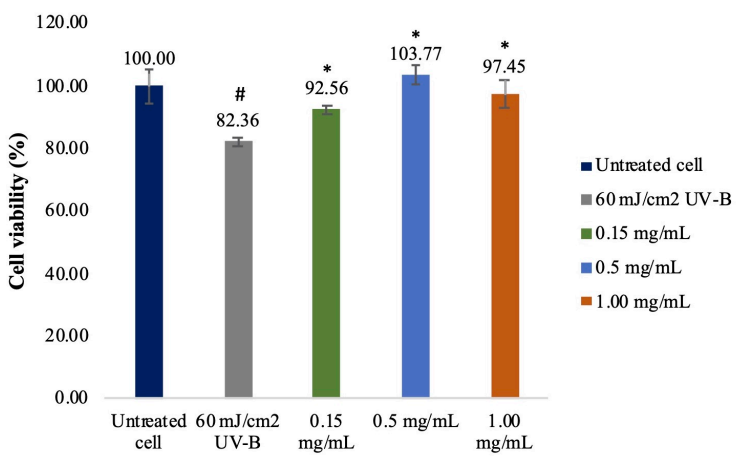

FIGURE 2 HDFa cellular viability analysis with tomato callus extract in aqueous solution. The results showed that UV-B exposure significantly decreased the cell viability compared with untreated cell ( $\left.{ }^{*} \mathrm{p}<0.05\right)$ and tomato callus extract with varying concentrations significantly increased the cell viability if compared with $60 \mathrm{~mJ} / \mathrm{cm}^{2}$ UV-B irradiated cells without pre-treatment extract $\left({ }^{*} p<0.05\right)$. Data are shown as a percentage of cell viability \pm standard error based on one time experiment using three wells.

the ability to increase the cell viability compared with the UV-irradiated cells without pretreatment with the extract. Both carrot and tomato callus extracts at the concentration of $0.5 \mathrm{mg} / \mathrm{mL}$ resulted in the highest percentage of viable cells, and hence, it was used as a reference concentration for the immunocytochemistry testing analysis. A previous study had also demonstrated that carrot callus extract at $0.5 \mathrm{mg} / \mathrm{mL}$ resulted in the highest percentage of viable cells induced by $\mathrm{H}_{2} \mathrm{O}_{2}$ radicals (Prastiandari 2018). Furthermore, a concentration higher than $0.5 \mathrm{mg} / \mathrm{mL}$, i.e., 1.0 $\mathrm{mg} / \mathrm{mL}$, had a cytotoxic effect on fibroblast cells induced by $\mathrm{H}_{2} \mathrm{O}_{2}$ (Khristina 2017).

Based on these findings, it can be suggested that both carrot and tomato callus extracts could contain components that either can act as antioxidants or have regenerative potential. It has been reported that the callus contains a protein component similar to that in animal cells, which is known as a retinoblastoma-related protein that participates in cell proliferation and division (Desvoyes et al. 2013). Furthermore, earlier research has demonstrated that the carrot callus aqueous extract contains glycoprotein compounds with molecular weights of 52.49 and $61.52 \mathrm{kDa}$ that have been reported to possess antioxidant and antiaging properties (Lee et al. 2015; Sekar 2016). Previous

TABLE 1 Cytokine expression in Human Dermal Fibroblast adult (HDFa) cells treated with callus extracts and UV-B irradiation.

\begin{tabular}{llll}
\hline Treatment & COX-2 expression \pm SE (\%) & TNF-a expression \pm SE (\%) & IL-10 expression \pm SE (\%) \\
\hline Untreated cell & $0 \pm 0.00^{\mathrm{a}}$ & $0.04 \pm 0.04^{\mathrm{a}}$ & $0.14 \pm 0.10^{\mathrm{a}}$ \\
$60 \mathrm{~mJ} / \mathrm{cm}^{2}$ UV-B-irradiated cell & $20.61 \pm 2.90^{\mathrm{b}}$ & $97.71 \pm 1.34^{\mathrm{b}}$ & $6.03 \pm 0.26^{\mathrm{b}}$ \\
Carrot callus extract $(0.50 \mathrm{mg} / \mathrm{mL})$ & $2.88 \pm 1.59^{\mathrm{c}}$ & $70.08 \pm 14.04^{\mathrm{c}}$ & $13.07 \pm 1.73^{\mathrm{c}}$ \\
Tomato callus extract $(0.50 \mathrm{mg} / \mathrm{mL})$ & $2.85 \pm 1.54^{\mathrm{d}}$ & $36.20 \pm 1.22^{\mathrm{d}}$ & $5.02 \pm 1.19^{\mathrm{b}}$
\end{tabular}

The results showed that UV-B exposure significantly upregulated the expression of COX-2, TNF- $\mathrm{a}$, and IL-10 in HDFa cells compared with the untreated cells ( $\left.{ }^{b, a} p<0.05\right)$. Carrot and tomato callus extracts at $0.5 \mathrm{mg} / \mathrm{mL}$ significantly decreased the expression of COX- 2 and TNF-a and also increased the expression of IL-10 in HDFa cells compared with $60 \mathrm{~mJ} / \mathrm{cm}^{2} \mathrm{UV}$-B-irradiated cells (c,b; d,b $p<0.05$ ). However, tomato callus extract at $0.50 \mathrm{mg} / \mathrm{mL}$ did not signicantly upregulate the expression of IL-10 in HDFa cells compared with 60 mJ/cm ${ }^{2}$ UV-B-irradiated cells $\left({ }^{b} p<0.05\right)$. Data are shown as the percentage of COX-2/TNF-a/IL-10 expression in HDFa cells \pm standard error based on one time experiment using three wells. 


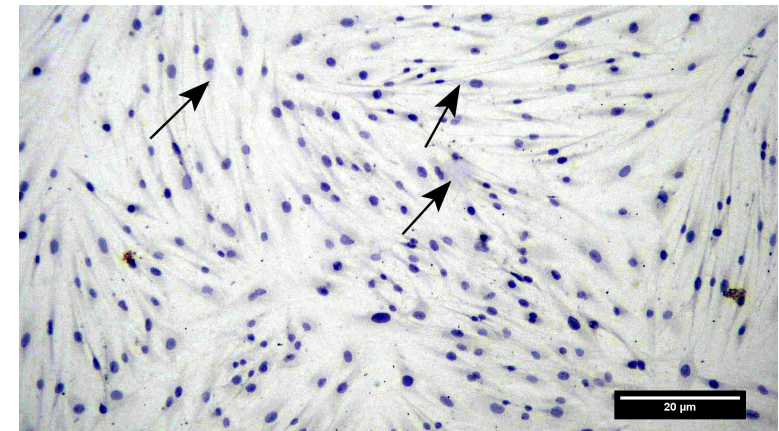

(a)

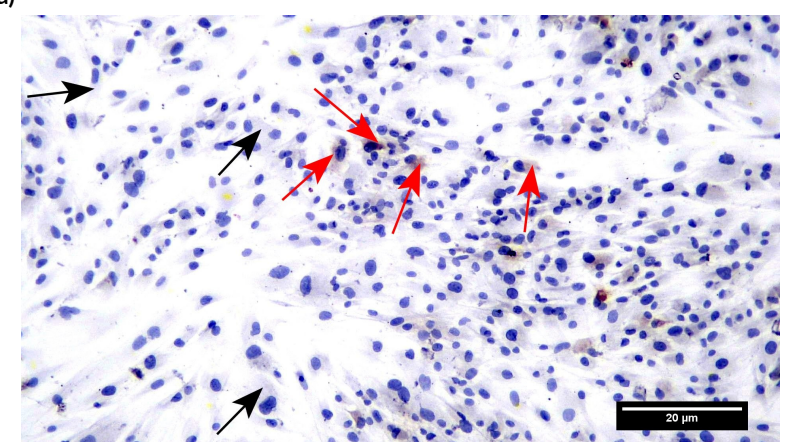

(c)

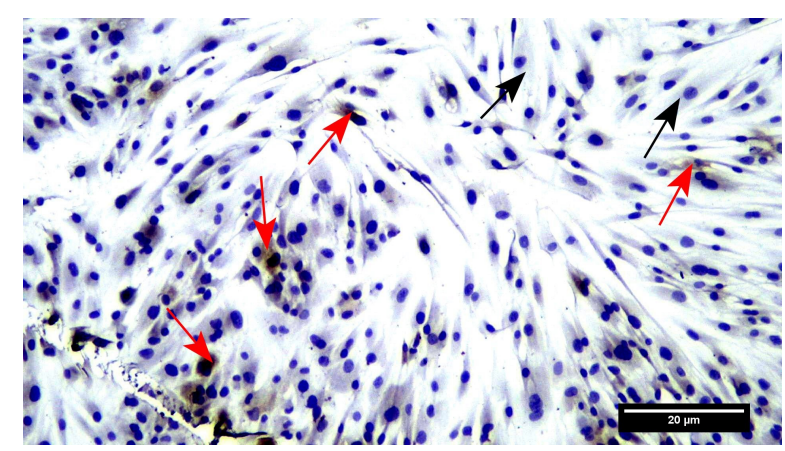

(b)

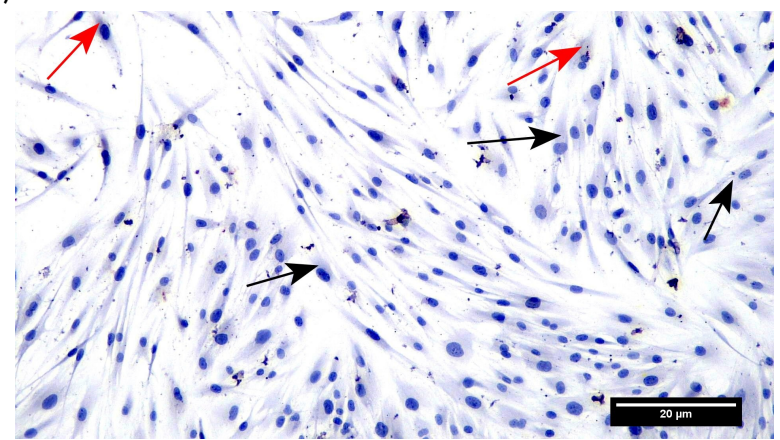

(d)

FIGURE 3 Expression of COX-2 cytokine in Human Dermal cells Fibroblasts Adult (HDFa) on a $20 \mu \mathrm{m}$ scale. (a) Untreated cell with antibody; (b) UV-B irradiated cell; (c) Carrot callus extract $(0.50 \mathrm{mg} / \mathrm{mL})$; (d) Tomato callus extract $(0.50 \mathrm{mg} / \mathrm{mL})$; Red arrow indicates COX-2 positive expression; black arrow indicates negative expression.

studies have also identified the antioxidant compounds in both extracts and suggested the presence of flavonoids, terpenoids, and phenolic compounds in the ethanolic extract (Sekar 2016; Prastowo 2017; Trehan et al. 2017), wherein the flavonoids and phenolic compounds were found to contribute to the antioxidant activity of the tomato callus extract that is known to be soluble in an aqueous solvent.

\subsection{Analysis of COX-2, TNF- $\alpha$, and IL-10 Expression in HDFa Cells by Immunocytochemistry Method}

The UV exposure is a potent inflammatory agent that has an ability to stimulate the production of inflammatory cytokines such as COX-2, TNF- $\alpha$, IL-16, and IL-10 (Kanagalakshmi et al. 2014; Kammeyer and Luiten 2015). In this study, using HDFa cells, we evaluated the effect of both carrot and tomato callus extracts in modulating the expression of COX-2, IL-10, and TNF- $\alpha$ after irradiation by UV-B light at $60 \mathrm{~mJ} / \mathrm{cm}^{2}$. It was observed that the cells showed positive expression of COX-2, TNF- $\alpha$ and IL-10 as indicated by a brown color in the cellular cytoplasm, as depicted respectively in Figures 3-5. Furthermore, as shown in Table 1, both carrot and tomato callus extracts had the ability to decrease the expression of COX2 and TNF- $\alpha$, as analyzed by the semiquantitative method using the ImageJ software. UV-B light exposure significantly upregulated the expression of COX-2 and TNF$\alpha$ in the HDFa cells to $20.61 \% \pm 2.90 \%$ and $97.71 \% \pm$ $1.34 \%$, respectively, which is because both COX-2 and TNF- $\alpha$ are proinflammatory cytokines that are stimulated in cells by ROS-induced UV-B exposure due to the activa- tion of mitogen-activated protein kinase (MAPK) signaling. Studies have reported that activation of the MAPK signaling pathway can increase the phosphorylation of P38, JNK, and ERK and lead to the production of NF-k $\beta$ transcription factor, thereby regulating the transcription of proinflammatory cytokines (Surowiak et al. 2014; Subedi et al. 2018). Proinflammatory cytokines can promote the breakdown of matrix components in fibroblast cells by stimulating the infiltration of immune cells, such as neutrophils, that can damage elastin and collagen in the fibroblast skin layer due to the accumulation of matrix metalloproteinases (MMPs)-1, -2, -3, -8, and -9 (Kammeyer and Luiten 2015). Pretreatment with the carrot callus extract significantly decreased the expression of COX-2 and TNF- $\alpha$ in HDFa cells to up to $17.73 \%$ and $27.63 \%$, respectively. Similarly, pretreatment with the tomato callus extract also significantly decreased the expression of both COX-2 and TNF- $\alpha$ to up to $17.76 \%$ and $61.51 \%$, respectively, compared to that in UV-B-irradiated cells without pretreatment with the extract.

Regarding IL-10 expression in HDFa cells, we found a significant increase in its expression in UV-B-irradiated cells to $6.03 \% \pm 0.26 \%$. IL-10 is an anti-inflammatory cytokine expressed in both immune and nonimmune cells and has a role in immunosuppression reaction. The increase in IL-10 expression after being induced by UV-B in HDFa cells can be possibly regulated by STAT-3 activation by UV-B exposure, which has an important role in the IL-10 cytokine activation pathway (Liechty et al. 2000; Bito et al. 2010). Pretreatment with the carrot callus ex- 

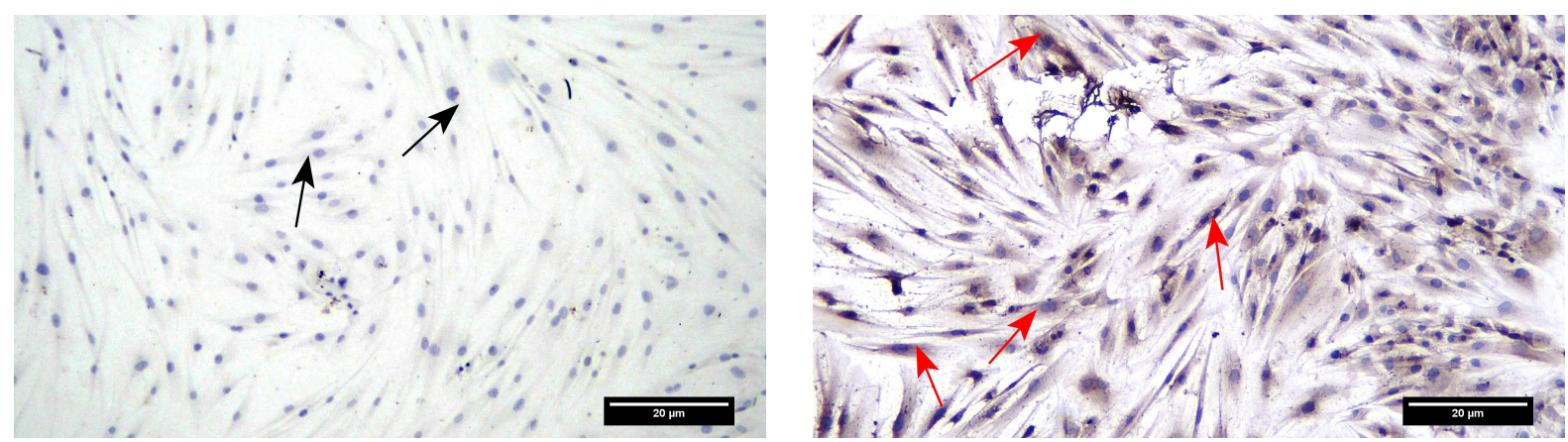

(a)

(b)
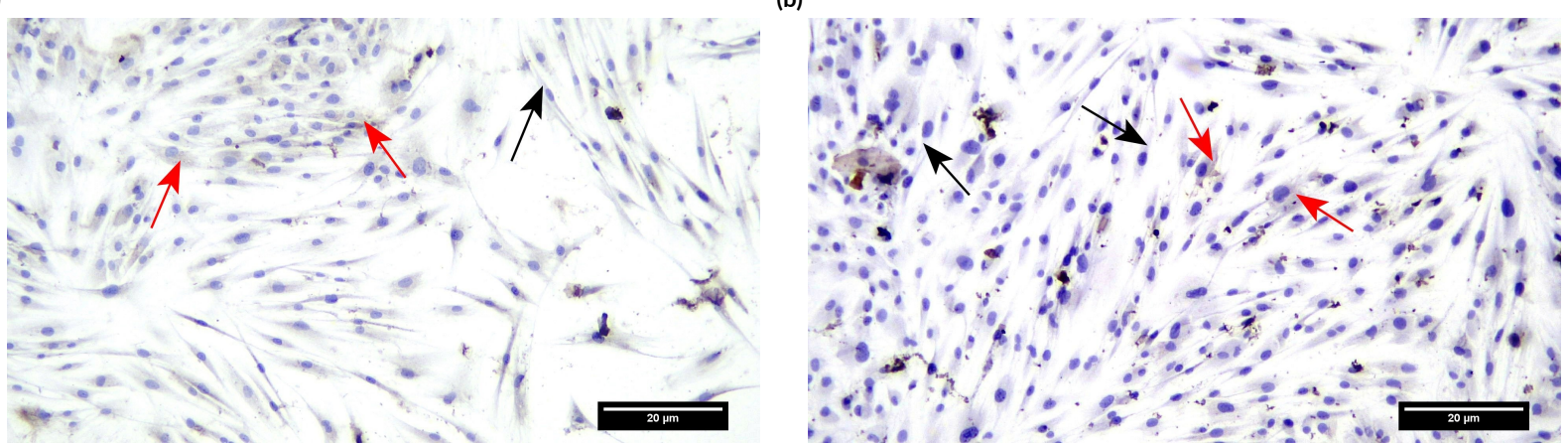

(c)

(d)

FIGURE 4 Expression of TNF-a cytokine in Human Dermal cells Fibroblasts Adult (HDFa) on a 20 $\mu$ m scale. (a) Untreated cell with antibody; (b) UV-B irradiated cell; (c) Carrot callus extract $(0.50 \mathrm{mg} / \mathrm{mL})$; (d) Tomato callus extract $(0.50 \mathrm{mg} / \mathrm{mL})$. Red arrow indicates TNF-a positive expression; black arrow indicates negative expression
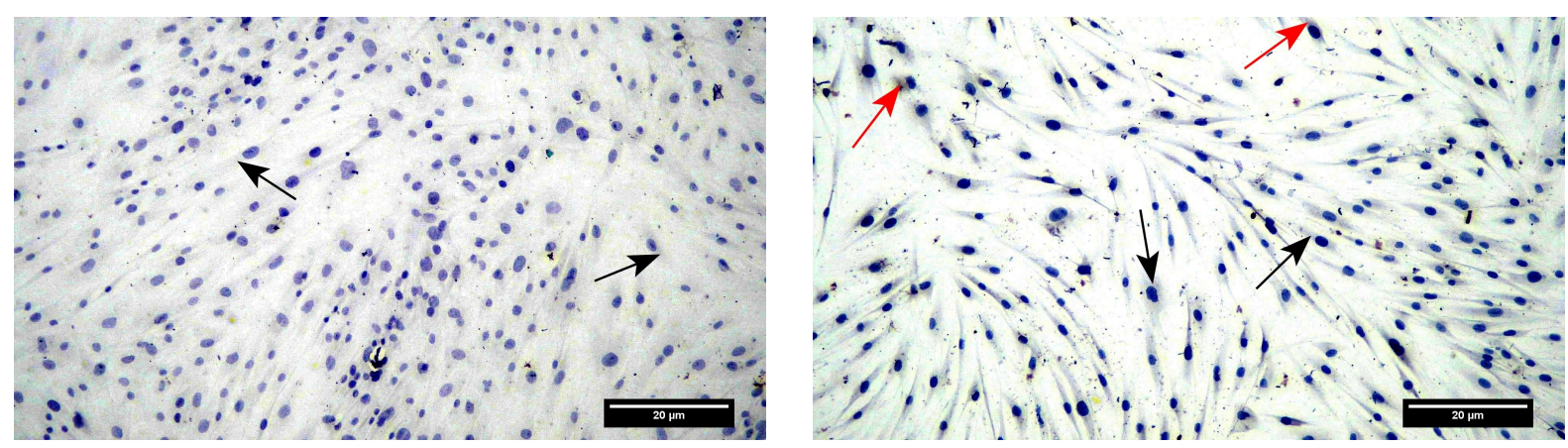

(a)

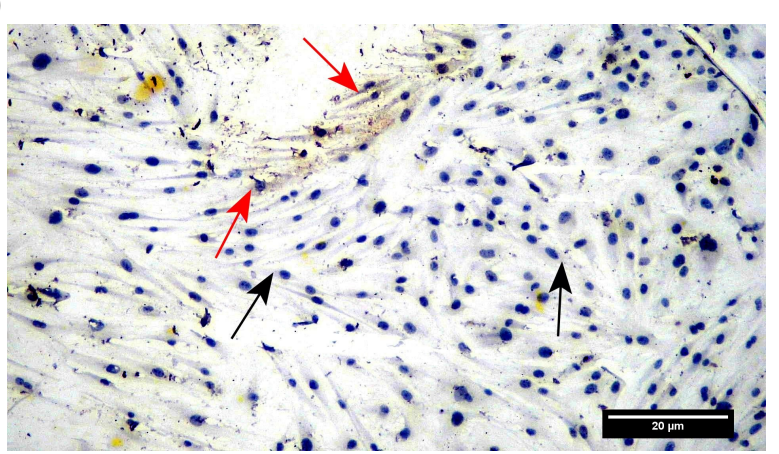

(b)

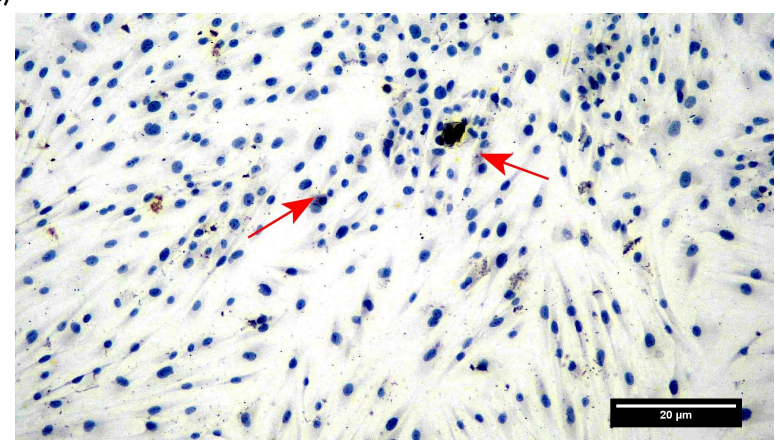

(d)

FIGURE 5 Expression of IL-10 cytokine in Human Dermal cells Fibroblasts Adult (HDFa) on a $20 \mu \mathrm{m}$ scale. (a) Untreated cell with antibody; (b) UV-B irradiated cell; (c) Carrot callus extract $(0.50 \mathrm{mg} / \mathrm{mL})$; (d) Tomato callus extract $(0.50 \mathrm{mg} / \mathrm{mL})$. Red arrow indicates IL-10 positive expression; black arrow indicates negative expression.

tract was found to significantly upregulate IL-10 expression in HDFa cells to $7.04 \%$ compared with that in UVB-irradiated cells, whereas pretreatment with the tomato callus extract did not increase IL-10 expression.

Results of this study indicate that both carrot and tomato callus aqueous extracts exhibited cytoprotective 
activities in HDFa cells exposed to UV-B light by significantly increasing the viability of HDFa cells and decreasing the expression of COX-2 and TNF- $\alpha$, whereas the carrot callus aqueous extract increased the expression of IL10 in HDFa cells. All these findings reinforce the idea of the cytoprotective activity of carrot and tomato callus aqueous extracts that have already been evaluated in this and previous studies. Since carrot and tomato plants can be easily found anywhere in the environment, future studies can aim at developing both carrot and tomato callus extracts for use as antiaging agents, considering that several people are exposed to free radical sources every day. However, these findings still need more reinforcement studies to develop a safe and innovative cosmetic that, in the future, could prevent skin damage and induce regeneration in human cells.

\section{Conclusions}

Carrot (D. carota L.) callus extract at concentrations of 0.05, 0.25, and $0.5 \mathrm{mg} / \mathrm{mL}$ and tomato (S. lycopersicum L.) callus extract at concentrations of $0.15,0.5$, and $1 \mathrm{mg} / \mathrm{mL}$ exhibited cytoprotective activity in HDFa cells against UV-B exposure by increasing the viability of cells compared to that in UV-B-irradiated cells without pretreatment with the extracts. Both carrot and tomato callus aqueous extracts at $0.5 \mathrm{mg} / \mathrm{mL}$ were able to decrease the expression of the proinflammatory cytokines COX-2 and TNF$\alpha$, whereas the carrot callus aqueous extract was found to enhance the expression of the anti-inflammatory cytokine IL-10 in HDFa cells.

\section{Acknowledgments}

This paper is a resume taken from three undergraduate theses (Apritadila 2019; Riastri 2019; Sari 2019) that are a part of the project with the principal investigator Dr. Rumiyati, M.Si., Apt, and was supported by research grants of PTUPT (Penelitian Terapan Unggulan Perguruan Tinggi) 2018 with number 1805/UN1/DITLIT/DITLIT/LT/2018.

\section{Authors' contributions}

R, S, ES, SW designed the study. DTS, BKA, AR carried out the laboratory work. DTS, BKA, AR analyzed the data. R, S, DTS, BKA, AR wrote the manuscript. All authors read and approved the final version of the manuscript.

\section{Competing interests}

The authors declare no competing interest.

\section{References}

Apritadila BK. 2019. Uji aktivitas sitoprotektif ekstrak air sel punca tanaman tomat (Solanum lycopersicum L.) dan analisis ekspresi COX-2 pada sel Human Dermal Fibroblast Adult (HDFa) yang diinduksi sinar UV-B [Cytoprotective activity test of tomato stem cell aqueous extract (Solanum lycopersicum L.) and analysis of COX-2 expression in Human Dermal Fibroblast Adult (HDFa) cells induced by UV-B light]. Undergraduate thesis, Universitas Gadjah Mada, Yogyakarta.

ATCC. 2011. MTT Cell Proliferation. American Type Culture Collection, Manassas.

Bito T, Sumita N, Masaki T, Shirakawa T, Ueda M, Yoshiki R, Tokura Y, Nishigori C. 2010. Ultraviolet light induces Stat3 activation in human keratinocytes and fibroblasts through reactive oxygen species and DNA damage. Exp Dermatol. 19(7):654660. doi:10.1111/j.1600-0625.2010.01084.x.

Desvoyes B, De Mendoza A, Ruiz-Trillo I, Gutierrez C. 2013. Novel roles of plant RETINOBLASTOMARELATED (RBR) protein in cell proliferation and asymmetric cell division. J Exp Bot. 65(10):26572666. doi:10.1093/jxb/ert411.

Dewi DA. 2018. Uji aktivitas penghambatan kematian ekstrak etanol dan air sel punca tanaman tomat (Solanum lycopersicum L.) terhadap human dermal fibroblast adult (HDFa) cell line yang diinduksi hidrogen peroksida $\left(\mathrm{H}_{2} \mathrm{O}_{2}\right)$ [The death inhibition test of ethanol extract and tomato plant stem water (Solanum lycopersicum L.) on human dermal fibroblast adult (HDFa) 's cell line induced by hydrogen peroxide $\left(\mathrm{H}_{2} \mathrm{O}_{2}\right)$ ]. Undergraduate thesis, Universitas Gadjah Mada, Yogyakarta.

Grandjean-Laquerriere A, Le Naour R, Gangloff SC, Guenounou M. 2003. Differential regulation of TNF$\alpha$, IL-6 and IL-10 in UVB-irradiated human keratinocytes via cyclic AMP/protein kinase A pathway. Cytokine. 23(4-5):138-149. doi:10.1016/S10434666(03)00224-2.

Hana CA. 2016. Analisis kandungan senyawa dominan dan protein dalam sel punca (stem cells) tanaman tomat (Solanum lycopersicum L.) serta uji aktivitas antioksidan [Analysis of the dominant compound content and proteins content in tomato plants (Solanum lycopersicum L.) stem cells and antioxidant activity test]. Undergraduate thesis, Universitas Gadjah Mada, Yogyakarta.

Kammeyer A, Luiten RM. 2015. Oxidation events and skin aging. Ageing Res Rev. 21:16-29. doi:10.1016/j.arr.2015.01.001.

Kanagalakshmi A, Agilan B, Mohana S, Ananthakrishnan D, Velmurugan D, Karthikeyan R, Ganesan M, Srithar G, Prasad NR. 2014. Ferulic acid modulates ultraviolet-B radiation mediated inflammatory signaling in human dermal fibroblasts. J Res Biol. 4(8):1505-1515. 
Khristina CA. 2017. Uji efek sitoprotektif ekstrak sel punca kecambah Wortel (Daucus carota L.) secara in vitro serta uji aktivitas antioksidan dengan metode FRAP [Cytoprotective effect test in carrot (Daucus carota L.) seed extract in vitro and antioxidant activity test with FRAP method]. Undergraduate thesis, Universitas Gadjah Mada, Yogyakarta.

Lee MJ, Jeong NH, Jang BS. 2015. Antioxidative activity and antiaging effect of carrot glycoprotein. J Ind Eng Chem. 25:216-221. doi:10.1016/j.jiec.2014.10.037.

Liechty KW, Kim HB, Adzick NS, Crombleholme TM. 2000. Fetal wound repair results in scar formation in interleukin-10-deficient mice in a syngeneic murine model of scarless fetal wound repair. J Pediatr Surg. 35(6):866-873. doi:10.1053/jpsu.2000.6868.

Prastiandari D. 2018. Uji sitoprotektif ekstrak sel punca tanaman wortel (Daucus carota L.) pada siklus cell line fibroblas yang diberi perlakuan dengan $\mathrm{H} 2 \mathrm{O} 2$ dengan metode flow cytometry [Cytoprotective test of stem cell carrot (Daucus carota L.) extract in cell line fibroblasts cycle treated with $\mathrm{H} 2 \mathrm{O} 2$ through flow cytometry method]. Undergraduate thesis, Universitas Gadjah Mada, Yogyakarta.

Prastowo D. 2017. Uji efek sitoprotektif ekstrak sel punca tomat (Lycopersicon esculentum Mill.) dan uji daya reduksi dengan metode FRAP (ferric reducing antioxidant power) secara in vitro [Cytoprotective effect in vitro test of tomato (Lycopersicon esculentum Mill.) stem cell extract and reduction power test by FRAP (ferric reducing antioxidant power) method]. Undergraduate thesis, Universitas Gadjah Mada, Yogyakarta.

Riastri A. 2019. Uji efek sitoprotektif ekstrak air sel punca kecambah tomat (Solanum lycopersicum L.) dan Analisis Ekspresi Sitokin TNF-Alpha pada Sel Human Dermal Fibroblast Adult (HDFa) yang Diinduksi Sinar UV-B [Cytoprotective effect test of tomato (Solanum lycopersicum L.) shoot stem cell extract and Analysis of TNF-alpha expression in $\mathrm{Hu}-$ man Dermal Fibroblast Adult (HDFa) cells induced by UV-B light]. Undergraduate thesis, Universitas Gadjah Mada, Yogyakarta.

Rumiyati, Sismindari, Nurrochmad A, Semiarti E, Widyarini S, Prastiandari D, Utama AD, Dewi DA. 2019. Cytoprotective activity of tomato and carrot callus on human dermal fibroblast adult (HDFa). In: AIP Conf Proc., volume 2099. AIP Publishing. p. 020021. doi:10.1063/1.5098426.

Sari DT. 2019. Uji efek sitoprotektif ekstrak air sel punca tanaman wortel (Daucus carota L.) dan Analisis Pengamatan Ekspresi Sitokin IL-10 pada Sel Human Dermal Fibroblast Adult (HDFa) yang Diinduksi Sinar UV-B [Cytoprotective effect test of carrot (Daucus carota L.) stem-cell aqueous extract and Analysis of IL-10 expression observation on Human Dermal Fibroblast Adult (HDFa) cells induced by UVB light]. Undergraduate thesis, Universitas Gadjah Mada, Yogyakarta.
Schmid D, Schurch C, Blum P, Belser E, Zulli F. 2008. Plant stem cell extract for longevity of skin and hair. Int J Appl Sci. 134(5):30-35.

Sekar G. 2016. Analisis kandungan senyawa dan protein sel punca kecambah wortel (Daucus carota L.) serta uji aktivitas antioksidan dengan metode DPPH (2,2-difenil-1-pikril-hidrazil) [Analysis of the compound content and protein content of carrot sprout stem cells (Daucus carota L.) and antioxidant activity test with DPPH method (2,2-diphenyl-1-pikrilhidrazil)]. Undergraduate thesis, Universitas Gadjah Mada, Yogyakarta.

Subedi L, Lee TH, Wahedi HM, Baek SH, Kim SY. 2018. Corrigendum to "Resveratrol-enriched rice attenuates UVB-ROS-induced skin aging via downregulation of inflammatory cascades”. Oxid Med Cell Longevity. doi:10.1155/2018/6052623.

Surowiak P, Gansukh T, Donizy P, Halon A, Rybak Z. 2014. Increase in cyclooxygenase-2 (COX-2) expression in keratinocytes and dermal fibroblasts in photoaged skin. J Cosmet Dermatol 13(3):195-201. doi:10.1111/jocd.12103.

Trehan S, Michniak-Kohn B, Beri K. 2017. Plant stem cells in cosmetics: current trends and future directions. Future Sci OA. 3(4):FSO226. doi:10.4155/fsoa-2017-0026.

Utama AD. 2018. Uji aktivitas sitoprotektif ekstrak etanol dan air sel punca tanaman tomat (Solanum lycopersicum L.) melalui modulasi profil siklus sel human dermal fibroblast adult (HDFa) yang dipaparkan hidrogen peroksida $\left(\mathrm{H}_{2} \mathrm{O}_{2}\right)$ [Activity cytoprotective test of ethanol extract and tomato (Solanum lycopersicum L.) plant stem water through cell cycle profiles modulation on human dermal fibroblast adult (HDFa) exposed by hydrogen peroxide $\left(\mathrm{H}_{2} \mathrm{O}_{2}\right)$ ]. Undergraduate thesis, Universitas Gadjah Mada, Yogyakarta. 